に区分できる．昨年 4 題の発表当初之比較し，内容の向 上は観られるものの，未だ基檚的な範䧃を脱していない， 発表形式は, 誌上 3 題, 口述 3 題で, 誌上発表者にも発 言の機会を与えるため, digest 発表を依頼し, 番号順に 進行して, 質疑討論はそれぞれの group 毎に行った. 以下, 各演題の要旨, および, まとめを記述する.

演題62: 常電導型装置を 1 階X線空を改造して設置し， 室外部の医療機器に与える影饗および外部動的, 静的磁 性体の影響を示した。使用上の経時変化で sealed 材の 破損等保守管理の重要性を述べている点, 必要事項之考 える.

演題63：常電導型垂直空心磁石装置を地下のBetatron 室を改造して設置し, 建物の鉄骨磁性体に依る画質の影 響をShimcoil の利用, coil の相対位置の変化で, 磁性 体の除去を検討し, 磁場の均一度を得て, 良結果を示し た.

演題64：永久磁石型装置の磁場分布执上び磁性体の影 響について検討し, 特に追加発表で, 小さな磁性体の影 響すなわち，医療の場で観られる，注射針，患者の hairpin等を刘照として考察した。実用性に富んだ良し研究 である。

演題65：NMR 上他の CT 画像之を42例, IR 像, proton 密度像, $\mathrm{T}_{1}$ 緩和時間像について, 比較した発表で, 臨床 的比較をして同一被検体を選ぶ困難さがあるが，今後， さらに研鑚され，Phantom と共に定義付けを望みたい。

演題66：NMR とX-CT の臨床頭部画像 150例の比較 で, pulse-sequences に依り画質が変化するが, 骨部の除 去が可能で, 軟部組織が鮮明であることを示した. 今後, 主磁石, 高周波磁場と画質について追試を依頼したい。

演題67: 永久磁石型で scan time, 緩和時間の測定に分 单位の時閏を要し, 動的被検体で, $\mathrm{T}_{1}$ 值, 画質の影響を 検討した. $\mathrm{NiCl}_{2}$ 水溶液では, 移動距離化影響なく, 周 期に影響して, $\mathrm{T}_{1}$ 值が下り, 動きはボケ像となるとと を示した.

〔質疑討論】 62〜64は特に質問，追加発言はなかっ た。

質問 (大河原脳外・有坂) 発表の中で検査時間の長い こと，分解能の低しとこの基準は何を比較対称とした か.

答 (65): X-CT と比較した. 今後 multiple-slice 方式 の発達により短縮され，画質屯改善されるであろう。

質問(阪大・段床) NMR-CT 腹部像の良否について。 答(66)：現況では scan time がかかか，被検体の動 きで, 細部、はっきりしないが, 整形外科領域で利用で
きる.

答(67)：頭部より大きい磁場が必要で, $\mathrm{S} / \mathrm{N}$ が悪く, 良い画質は得られず，画像上，X-CT 上り落ちるが，他 飞 sagittal 画像, coronal 画像が得られる利点がある.

〔ま之め] NMR はその特徵から医療分野への可能性 が秘められており，臨床的に応用伸展が望まれている。 本席では, Layout, 磁場の保護, 環境の保護, $\mathrm{T}_{1}, \mathrm{~T}_{2}$ 值 の測定および，臨床応用例比較が示された。現在, phantom の素材す基礎的段階で，測定方法す一定でないので， 基準 test-phantom を作成して, 主磁石, 磁力の差, 高 周波磁場の操作, pulse-sequences の処理等に依る異な った画質，值について注目し，検討していか称ばならな い. $\mathrm{T}_{1}, \mathrm{~T}_{2}$ 值む測定比較可能であるてと以外に, 装置差 間の統一性が望まれる。他の CT 画像との比較沈いて は, それぞれ，生理的, 解剖学的の目的が異なるので, それを同一 level で比較するこ之は良い手法ではない が, 他の CT とは異なった情報が得られる等の利点も多 い. 唯一の欠点は検查処理時間を要することであるが， とれも現代の electronicsでは近き将来解決できるもの 上考える.

\section{X-CT-3 ダイナミック}

\section{座長 山下 緑 (東関遇信病院)}

\section{CT を用いた Functional Imaging 一頭部への応用一}

国立循環器病センター放射線譒療部

○坂下善治・大西義隆

小倉裕樹・佐久間利治

〔目的〕CTKよるダイナミックスタディをデータ解 析して得られる functional image は, 各ピクセルにおけ る血流動態の変化を各パラメータごとに CRT 上に濃度 変換して表示し, 視覚的に血流循環状態を観察できるよ うにしたものである．今回，人体において大小に富む多 数の血管を含み灌流領域の複雑な頭部への応用を試みた ので, 臨休的佂值と精度を検討した。

〔結果】 functional imageでは,ピクセルごとの計算 值が表示されるため循環時間の異なった部分が複雑に入 りくんでいる様子がよく観察でき, 周团の梗塞や大血管 の循環状態に影響を受けない高精度の細分化された情報 が得られた。

69. Cardiac scan system の開発とその臨床応用 独協医科大学病院放射線部 ○松村義光・三代 忠・宇賀神 誠 幕田節男・杉原由美子 
独協医科大学越谷病院放射線部

會前 茂

東芝那須工場 CT 技術部 藤瀬正邦・啮川秀三 井上順二・朝比奈清敬

約 2 年前に, 東芝製 CT-scanner, TCT-60A-30type 亿 gated cardiac scan system 導入し, hardware, software の開発および scan technic 等の検討をし，現在で は monitor 上で心臓の実時間的な動きを表現可能にな っている.今回は，機能診断への忘用として，心駆出率 (EF) 算出の software を開発し検討しているので,これ らについて報告した，基礎実験として風船の容積を本 system で算出した結果，2〜3\%の愦差であり，また医師 之の共同動物実験（犬）で実際に左室容積， EF を求めた が臨床では造影剤の使用量に限度があり，乙の点等につ いて検討した結果，造影郕注入終了 3 分以内であれば自 動輪郭表示可能であり，充分機能診断手技として導入可 能であることがわかった。

\section{0.「Stable Xenonを用いた $\gamma$-CBF の測定」動脈採血 法および Shunt 法}

慶応義熟大学病院 CT スキャン空 ○宗像雅則・鈴木 保 朝倉 崇・栗原政沖

[発表後抄録末提出]

71. 心電同期型 CT アルゴリズムの検討とその臨床応用 (株) 日立メディコ ○作藤一弘 筑波記念病院放射線科 鈴木利一

心臓の静止断層像を得るゲートCT では計測データが 少ない場合，投影データ不足によるアーチファクトを減 らすためゲート幅を広げるととによる画質劣化が問題と なる．他方，X線被曝の点からは少ない計測データで画 像を得るととと，モーションアーチファタトを減らすた めにはせまいゲート幅を用いるととが必要である。この ようなゲート CT の特性をむとに，少数投影データから の像再構成アルゴリズムとして最大エントロピー法を導 入し，理諭検討および臨床実験を行った。実験では 3 ス キャンのデータから，位相分割数 8 , ゲート愊 $50 \mathrm{~ms}$ に より良好な断層像を再構成でき, 実用によるととを示し た。

\section{2. 解離性大動脈瘤の CT 検査法について}

東京女子医科大学病院放射線科
当院では解離性大動脈瘤の CT 検榃方法について基準 化を行ったが，それにあたっての条件は(1)必要な診断情 報が充分得られること，(2)検查時間力゙可能な限り短いこ 亡,(3)スキャン数が可能な限り少ないとと, の3つであ る.乙れにもとづく実際の内容は(1)原則的に胸部と腹部 とは別々の検查とする，(2)胸部は大動脈引から肝蔵上部 まで，腹部は肝臓上部から大動脈分伎下まで $4 \mathrm{~cm}$ 間隔 で造影前のスキャンをする. (3)乙れをもとにしてダイナ ミック CT を行う，(4)造影後は $2 \mathrm{~cm}$ 間隔で必要な範罒 をスキャンする．以上のでとくであるが，基準化するこ とによって有效な彰断情報を20分程度の短い検查時間で 得ることができるようになった。

\section{CT による肺換気動態の測定 [第 1 報】}

関西医科大学附属香里病院放射線科

○水野正善・岡橋弘和・㷊本克己 米田義英・平田靖裕・榷 昭則 西井 徹

非放射性 Xe ガス濃度の变化による CT 值の変化, お よび獅内関心領域の大・小の設定による CT 値の変化を 検討した。非放射性 Xe ガス浱度と CT 值との間に，直 線関係があり，CT 值で約 170 の変化が見られるととよ り，䏳換気動態の測定に使用し，CT 值の変化上り動態 の把握ができると考える。関心領域を大きく設定した時 は, 肺換気の肺葉単位の把握ができ, 絶対值より, 相対 值の方が，局部別の変化を比べやすい．小さく設定した 時は，肺区域のみの場合には，SD 值も小さくなり精度 屯上がるが，大きな血管を含む場合は，グラフからの動 態把握が困難である。本法も RI 法とは違った有用性を 認めたが，今後の改良，検討在有する問題す多い。

\section{CT における Dual Energy Subtraction}

東京女子医科大学脳神経センタ一神経放射線科

○森山紹敏・米山利男・阿曾源一郎 吉田滋俊・江島光弘・臼井一徳 安藤 博・小野寺浩幸

当院所では CT 撮影において，X線管電压 $80 \mathrm{kV}$ と $120 \mathrm{kV}$ 間の dual energy subtraction 法を臨床に応用し ているので報告する，基礎実験でも確認されたが，臨床 例でも dual energy subtraction によって脳内の血腫は 消失し, 石灰化や低濃度でも造影された部分は描出され た。

この方法の有用性としては, 通常の subtraction 像と 比較して同条件下で連続 scan するため患者の動きがな いとと，周りの血腫等を除くことにより造影部分だけを 視覚的に特徴づけられること，脸室内など低い density 